\title{
Value-oriented leadership in the Netherlands
}

Paper for the RSA Annual International Conference in Newcastle-upon-Thyne Sunday 17th - Wednesday 20th April 2011.

\section{L.G. Horlings ${ }^{1}$}

\section{Introduction; the call for 'inner' leadership in sustainable development}

The core of the European Lisbon and Gothenburg agenda's is the call for integrated solutions in regions towards economic prosperity, social cohesion and environmental sustainability. European regions face challenges on issues such as climate, energy, food, migration and poverty. It is becoming much clearer that any effective adaptations to environmental and resource vulnerabilities will need to be inherently 'place based'. That is they will have to accommodate the particular heterogeneity and diversity of localities and regions.

In the long run localities and regions should anticipate sustainable development to prevent unfair competition (OECD, 2006; Millennium Ecosystem Assessment, 2005). Sustainable development is a normative concept referring to the responsibility to make short-term decisions from a long-term perspective on sustainability, taking the effects on future generations and a range of geographical scales into account. Since the presentation of Our Common Future (WCED, 1987) 'sustainable development' has become a leading concept in policies related to the environment. It has recently become a central theme in regional development as well (Pike and Rodriguez-Pose, 2006).

Quental et al. (2011) note that sustainable development has become an ever more encompassing framework over the past decades. Sustainable development no longer only applies to pollution control, the availability of natural resources and protecting species and their ecosystems, but also to human and social development, including human rights, good governance and solidarity. Yet, as the authors note, it is a great challenge to bring these ambitions into practice. It has been noted that social sustainability has largely been neglected in policy and research (Cuthill, 2010) and economic sustainability is often uncritically linked to 'global capitalist' economies, thereby underestimating the importance of local and regional community-based economies (Gibson-Graham, 2008).

Sustainable development can be seen as a quest for developing and sustaining 'qualities of life' and thus contains objective and subjective dimensions (De Vries and Petersen, 2009). Sustainability should therefore not be studied as a 'value-free' science but as a science inclusive of values and responsibilities (Rajeswar, 2010). A prime research focus should be the complex interaction between the objective, exterior and the subjective, interior dimensions of sustainable development, including world views and culture (Hedlund-de Witt, 2011). Hay states:

'Without attention to how we view ourselves and the world (philosophy), what forms of improvement appear to be most appropriate (development) and how to motivate and help direct us to get there (leadership) any program to address sustainability is only superficial' (Hay 2010, p.163)

Some scholars see the current ecological crisis as a direct consequence of the way how people relate to nature, to other humans and to themselves (Scharmer, 2005). According to Wilber an underestimation of the inner, subjective part of realities leads to the view that there is no reality outside material objects. In his view the ecological crisis is not one of pollution, climate change and so on, but a reflection of the fact that human beings did not develop a post-conventional, universal and comprehensive consciousness. Only an inner transformation from egocentric, socio centric to world centric, can therefore create real commitment with Gaia (Wilber, 2000).

Also Zoeteman (2009) stresses the inner personal dimension. He distinguishes different attitudes for sustainability. Now that environmental problems occur in more spheres and on higher scales, we need a kind of morality that is adapted to this complexity and an appropriate attitude of sustainability. Today's post-industrial society challenges regions to invest in sustainability. But how to develop agency in this field and include the subjective personal dimension? We argue here that the 'human factor' plays an important role in sustainable regional development. Especially (formal and informal) leadership is a key-factor in regional development (Collinge \& Gibney 2010 ; Liddle, 2003).

${ }^{1}$ Dr. L.G. Horlings is working as a researcher and lecturer at the Rural Sociology Group, Wageningen University and Research centre, The Netherlands. E-mail: Lummina.horlings@wur.nl. 
Studies have shown that leadership matters and cannot be ignored (Collinge \& Gibney, 2010; Collinge et al, 2010; Sotarauta, 2006, 2010; Milner and Joyce, 2005; Stimsom et al, 2009). As Liddle (2003) points out, leaders work in un-chartered territories, beyond traditional boundaries with state, non-state, business, and auxiliary (universities, trade unions, charities, third sector). They seek to make sense of new situations, personnel, processes, and dynamic policy shifts. Although social agency constrained by the structural, institutional and historical context (Pike et al, 2007, p.1261), leadership capacity is a quality which can alleviate the negative consequences of economic regional development and to reinforce the positive ones (Bridger and Alter, 2008).

When we use the term leadership we don't refer to the typically strong, charismatic leader with a formal position \& power, but all those who, following their inner consciousness and inner values, take responsibility and actions for sustainable development in their own communities, localities and regions. Passion and commitment and the capability to mobilise others are essential in this process (Horlings et al., 2009). However, we know a great deal about what leaders do, but very little about the inner place, the source from which they operate. Change today not only requires a shift of the mind, it requires a shift of will and a shift of the heart.

To understand leadership four different 'field structures of attention' can be identified, levels which affect not only the way people listen, but also how group members communicate with one another, and how institutions form their geometries of power: 1) thinking (individual); 2) conversing (group); 3) structuring (institutions) and 4) ecosystem coordination (global systems). The way leaders pay attention to a situation, individually and collectively, determines the path the system takes and how it emerges. On all four levels - personal, group, institutional, and global-shifting from reactive responses and quick fixes on a symptoms level (Fields 1 and 2) to generative responses that address the systemic root issues (Fields 3 and 4) is the single most important leadership challenge of our time (Scharmer, 2008, p.55).

This leads to the question of this paper: how do leaders operate on different levels in regional development? The aim of this chapter is to link the challenge of sustainability in regional networks to what we will describe as the 'inner and outer' worlds of leadership. We will use a model of leadership which includes both subjective aspects of leadership and objective aspects how leaders work in networks and within the institutional environment. We will also illustrate this with four stories of entrepreneurs working as 'leaders of change' in the Netherlands. Furthermore we will analyse the findings of eight cases of regional development in the Netherlands where leadership played an important role.

\section{A value-oriented model of leadership}

To analyze leadership for sustainable regional development we include values, by using a 'value-based leadership model'. 'Value-based' means taking the subjective motives, values and opinions of leaders into account (among other factors). As Pike et al. state, people in places make value-based judgements about priorities and what they consider to be appropriate 'development' for their localities and regions (Pike et al, 2007, p.1255). This means we have to include the inner subjective dimension of people's actions towards sustainability. We used Wilber's (2000) Integral Theory as a starting point because it offers a holistic framework. His four quadrants model is organized around two axes: the individual versus the collective dimension and the subjective versus the objective dimension. This creates four quadrants, described as the I (subjective), IT (objective), WE (inter-subjective) and THEY (interobjective) dimension. The inner subjectivity of an individual has a direct imprint on the way he or she engaged with outer material world; vice versa, the 'objective' material world impacts the way subjective aspects are developing. So both the objective and subjective should be present in individual and collective domains.

This model has been translated to leadership in the context of regional development (Horlings and Padt, in press). In Table 1 four dimensions of leadership are presented. The upper row represents the individual perspective and the bottom row the collective perspective. The left side refers to the subjective inner world and the right side to the objective outer world. The resulting quadrants are referred to as I (upper-left), IT (upper-right), WE (lower-left) and THEY (lower-right). We have labeled these dimensions as 'shared leadership' (WE), creating 'vital space' (IT), 'bricolage' (THEY), and the 'X-factor' (I). We will explain these dimensions here shortly (see Horlings, 2010; Horlings and Padt, in press, for a more detailed explanation). We start with the 'WE-dimension' because this is the most obvious dimension of leadership: the capacity to work in regional networks of people with different opinions and values. 


\begin{tabular}{|l|c|c|}
\hline Individual & \multicolumn{1}{|c|}{ Inner World } & \multicolumn{1}{c|}{ Outer World } \\
\hline 'The X-factor' & \multicolumn{1}{c|}{$\begin{array}{c}\text { 'Vital space' } \\
\text { Inner motivation and } \\
\text { passion, rooted in human } \\
\text { values }\end{array}$} & $\begin{array}{l}\text { Stimulating favourable behaviour } \\
\text { towards sustainable development, } \\
\text { anticipating the extant governance } \\
\text { context }\end{array}$ \\
\hline Collective & 'Shared leadership' & \multicolumn{1}{c|}{ 'Bricolage' } \\
\hline $\begin{array}{l}\text { Dealing with visions and } \\
\text { values in networks }\end{array}$ & $\begin{array}{l}\text { Connecting networks in institutional } \\
\text { arrangements to cope with } \\
\text { sustainability challenges }\end{array}$ \\
\hline
\end{tabular}

Table 1. Dimensions of 'value-oriented' leadership for sustainable regional development (Horlings and Padt, in press).

WE-dimension

The WE-dimension refers to the cultural (inter-subjective) dimension of leadership, to the ability to bring together a variety of ideas and opinions on how to bring about change. How can leaders do this? There is a huge amount of literature on change management in organizations (e.g. Schön, 1973, 1983; Couperrider et al., 2008; Rowly and Roevens, 1999; Scharmer, 2005). These approaches, however, are too limited to explain how to bring about sustainable regional development for two reasons.

First, leaders are required to lead in multi-actor regional networks beyond the boundaries of organizations and in spheres where their actions and words may have influence despite having no authorization. Such leadership is not a simple matter of leaders and followers but is acting in networks. Second, leadership for sustainable development is dealing with multiple visions and trying to align people around a joint vision. It is not about realizing ego-driven goals, but adapting to the higher goal of required societal change, i.e. sustainable development.

Sotaurata $(2002,2005,2006)$ brings together both aspects in extensive research done on leadership in a regional context. The author states that such leadership requires network skills like teamwork,

interactive influencing and 'visioning between visions', but also skills to create creative tension and to generate excitement and arousal. He refers to leader tasks such as 'collective sense-making' and 'storytelling' (Sotarauta, 2002, p. 204-206).

Yet, there is more. Leadership in networks faces the risk of voluntarism. For sustainable development the 'outer world' needs to be changed as well.

\section{The IT-dimension}

The individual objective IT-dimension refers to how people behave and how they act or conduct themselves towards others in the network, i.e. their perceptible behaviour. Regional development takes place in different governance contexts, such as autonomy, competition, hierarchy and self-governance. There is no single preferred governance context for sustainable regional development. Each can be appropriate and satisfying as long as they contribute to the identity of the network, the willingness to provide authentic input and to a positive attitude (Wielinga 2001). However, each situation and governance context has a potential negative or regressive side: autonomy can degenerate into isolation, competition into power struggles; hierarchy can turn into dominance and self-governance can become bogged down in 'groupthink' (Wielinga, 2001; 2005).

Leaders play different roles in regional development processes. They can create and maintain 'vital space' where trust, specialization, division of tasks, and creativity can flourish. To show positive behavior a leader can take on a role as inspirator, negotiator, mediator or clown. Leadership roles can be also antagonistic. This behavior is effective when 'position play' is necessary, aimed at creating a certain position in the network and gaining respect, by using power and resources. Leadership roles displaying antagonistic behavior mirror the stimulating ones and can be described as the strategist, fighter, prophet, and regulator.

Yet, there are limits to what a leader can achieve. The institutional context defines the degree of freedom of regional leaders. This context may offer barriers to sustainable development and then it should be challenged. 


\section{The THEY-dimension}

The inter-objective THEY-dimension of leadership refers to the interaction of leaders and 'their' network within an institutional context. In the regional arena initiatives often encounter problems related to environmental regulation and procedures, sector-based internal organizations of governments, lack of cooperation between entrepreneurs, lack of trust, clashing interests, psychological dynamics and the physical and social characteristics of the regional context (Horlings and Van Mansfeld, 2006; Horlings and Haarmann, 2008; Van Mansfeld and Van der Stoep, 2007). The emotions resulting from this like despondency, anger, despair and distrust can easily lead to lock-in situations.

Leadership requires the ability to 'un-lock' situations, to build bridges between organizations and to mobilize actors in a process of dialogue. They work as 'boundary spanners' in public-private cooperation (Jones and Noble, 2008; Noble and Jones, 2006), constantly switching between different cultures, logics and languages (Klein and Teisman, 2003) and developing personal and emotional bonds based on mutual trust, commitment and respect (Jones and Noble, 2008, p.111). It is the art of 'institutional bricolage' to deal with the institutional context in an effective way. Bricolage is derived from the French verb bricoler, meaning to tinker or to fiddle, which comes close to the English phrase do-it-yourself. Yet this is not a technical fix. Personal commitment to sustainable development, inner motivations and passion are important, but an often forgotten dimension of leadership.

\section{The I-dimension}

What keeps leaders of change motivated and energetic; what keeps them going? And how do leaders make other people feel enthusiastic? What makes them able to mobilize people around sustainable regional agendas? This subjective dimension is a relative new area of research. Still very little is known about the 'source dimension' of effective leadership and social action (Scharmer, 2005):

'Why do our attempts to deal with the challenges of our time so often fail? The cause of our collective failure is that we are blind to the deeper dimension of leadership and transformational change. This 'blind spot' exists not only in our collective leadership but also in our social interactions. We are blind to the source dimension from which effective leadership and social action come into being'(Scharmer, 2008, p.52).

Recent empirical research in the Netherlands indicates that facts, feelings and emotions together play an important role and contribute to informal personal understanding between people (Horlings and van Mansfeld, 2006). Inspiration, passion, energy and inner motivations are crucial for realizing effective coalitions, when facing obstacles. Especially passion is necessary to persist during long processes of cooperation. It is the ' $\mathrm{X}$-factor' in regional development, impossible to grasp and steer, but the basis for sustainable regional development (Horlings et al., 2009).

Whereas in the other dimensions sustainable development is mostly expressed in technical and economic terms, in the I-dimension it becomes a personal matter. Contemporary rural transformation processes may make people feel uncertain about the future. The inner desire to make the world a better and more sustainable place can offer such a sense of direction (Horlings et al., 2009, p.26). For leaders this might be a source of doubt and insecurity because personal motivations and formal political choices not always align. We might say there is a distance between a leader's personal motivation for sustainable regional development and the environment she or he is working in. In our society an anthropocentric philosophy is dominant based on the belief that humans can manage planet Earth and have a right to use its resources primarily for ourselves (Hay, 2010, p.165). Political power, financial profit and technological progress have become dominant values in Western societies which alienates people from their environment (Tarnas, 2008). What is needed, according to Tarnas, to reconnect people to their environment is a more value-oriented motivation and passion that guides daily practices. People's inner motivation and passion is based on the Greek word pneuma which means 'breath or spirit'; it refers to the vital spirit, soul, or creative force of a person. The inner passion of people refers to their beliefs rooted in human values.

\section{Leaders of regional change in the Netherlands}

Empirical research was performed in eight Dutch regional cases in the Netherlands (Horlings, 2010). These cases ensure a range of contextual variation in terms of location, the size of the project, the sectors involved and the goals pursued. The cases illustrate regional processes where private leaders play or played a key role as chairman, initiator or otherwise (see Table 2). Data were collected over 
two years from interviews with the leaders, participative observation during meetings and available documentation. The interviews, which were based on open-ended questions, were structured around the WE, IT, THEY, and I dimensions of the leadership model. In the following sections we will describe four of the leaders more in detail to illustrate how leaders act in regional networks.

\begin{tabular}{|c|c|c|c|}
\hline Project & Private organisation & Leader & Strategy \\
\hline $\begin{array}{l}\text { Overdiepse polder } \\
\text { (Noord-Brabant) }\end{array}$ & $\begin{array}{l}\text { Overdiepse polder } \\
\text { interest group of } \\
\text { farmers }\end{array}$ & Dairy farmer & $\begin{array}{l}\text { Adaptive regional plan to create space } \\
\text { for rivers and respond to climate change } \\
\text { by moving farms to higher ground }\end{array}$ \\
\hline Sjalon (Flevoland) & $\begin{array}{l}\text { Sjalon business } \\
\text { partnership }\end{array}$ & $\begin{array}{l}\text { Horticulture } \\
\text { grower }\end{array}$ & $\begin{array}{l}\text { Innovative management arrangements } \\
\text { for scaling up agricultural practices in a } \\
\text { New Large Farm }\end{array}$ \\
\hline $\begin{array}{l}\text { Northern Frisian } \\
\text { Woods (Friesland) }\end{array}$ & $\begin{array}{l}\text { Northern Frisian } \\
\text { Woods Association }\end{array}$ & Dairy farmer & $\begin{array}{l}\text { Regional steering of nature and } \\
\text { landscape management by an } \\
\text { Association of farmers who also adapt } \\
\text { their farm management to reduce } \\
\text { mineral inputs collectively. }\end{array}$ \\
\hline $\begin{array}{l}\text { The New Mixed } \\
\text { Business (Limburg) }\end{array}$ & $\begin{array}{l}\text { New Mixed Business } \\
\text { partnership }\end{array}$ & Chicken farmer & $\begin{array}{l}\text { Clustering of different intensive } \\
\text { agricultural sectors to minimize transport } \\
\text { distances, reduce fossil energy use and } \\
\text { close energy-, minerals- and waste loops }\end{array}$ \\
\hline $\begin{array}{l}\text { New contracts with } \\
\text { the city in Waterland } \\
\text { (Noord-Holland) }\end{array}$ & $\begin{array}{l}\text { The organisations } \\
\text { Landzijde and My } \\
\text { Farmer }\end{array}$ & $\begin{array}{l}\text { Director of } \\
\text { Landzijde }\end{array}$ & $\begin{array}{l}\text { Regional approach of care-farming, } \\
\text { organized by Landzijde, a commercial } \\
\text { business and knowledge centre on } \\
\text { farming and care which coordinates the } \\
\text { placing of a variety of clients needing } \\
\text { day care at } 87 \text { farms. }\end{array}$ \\
\hline $\begin{array}{l}\text { Arkemheen Eemland } \\
\text { Regional Innovation } \\
\text { Centre (Utrecht) }\end{array}$ & Eemland Farm & $\begin{array}{l}\text { Owner of the } \\
\text { Eemland Farm } \\
\text { and dairy farmer }\end{array}$ & $\begin{array}{l}\text { An educational and multifunctional farm } \\
\text { as part of a regional process, developing } \\
\text { new knowledge arrangements and } \\
\text { alliances between town and country. }\end{array}$ \\
\hline $\begin{array}{l}\text { Regional Branding of } \\
\text { Het Groene Woud } \\
\text { (Noord-Brabant) }\end{array}$ & $\begin{array}{l}\text { Regional Cooperative } \\
\text { Association }\end{array}$ & $\begin{array}{l}\text { Strawberry } \\
\text { farmer }\end{array}$ & $\begin{array}{l}\text { Process of regional branding to } \\
\text { strengthen the regional economy while } \\
\text { preserving landscape quality. }\end{array}$ \\
\hline $\begin{array}{l}\text { New Markets } \\
\text { approach in } \\
\text { Heuvelland } \\
\text { (Limburg) }\end{array}$ & $\begin{array}{l}\text { Orbis Medical and } \\
\text { Healthcare Group }\end{array}$ & $\begin{array}{l}\text { Ex-member of } \\
\text { the board }\end{array}$ & $\begin{array}{l}\text { Strategy to link economic developments } \\
\text { to regional qualities and to attract large } \\
\text { rural and urban entrepreneurs to invest in } \\
\text { the landscape, in order to develop new } \\
\text { markets based on alliances between } \\
\text { different sectors such as agriculture, } \\
\text { tourism and health. }\end{array}$ \\
\hline
\end{tabular}

Table 3. Empirical case-studies 


\section{Case 1: An entrepreneur aligning city and countryside in the region Waterland}

The Waterland region near Amsterdam is a fen meadow area of high landscape quality. The region faces urban pressure and a decline in agricultural perspective and is looking for new sources of income to benefit from the proximity of Amsterdam. The organization Landzijde ('Landside') is a commercial business and knowledge centre on care-farming that coordinates the placing of a variety of clients needing day care at 87 farms.

Landzijde launched the 'Green Care Amsterdam' project, which seeks to realign city and countryside. This project started in 2008. The farmers in Landzijde work with the City of Amsterdam to provide care, shelter and day activities for people with psychological problems and reintegrating drug addicts in the city of Amsterdam.

The sustainability gains of the projects are mainly on Profit aspects, by creating new income sources for farmers and People aspects, by caring for different clients in rural as well as urban areas.

The initiator Jaap Hoek Spaans, initiator and director of Landzijde, is a leading figure in this region. He also runs a farm near the city of Amsterdam, has a large network and played an important role as temporary chairman of a national Taskforce, which stimulates multifunctional agriculture. 'Modern, multifunctional farming, taking the market into consideration, offers solutions for urban problems,' he argues. He is an optimist and has not encountered really difficult institutional barriers so far. Although there are some differences of opinion between actors, and in the beginning the farmers' union was very doubtful about the project, intensive lobbying of this leader at the local councils has generated support. Hoek-Spaans personal goal and motivation is to establish new rural-urban coalitions. In his words: 'Farmers have to offer citizens recreation, care and food. We have to give new meaning to the area'. Hoek Spaans develops networks of people who want to work professionally: 'I believe strongly in regional networks that are specialised in aspects of multifunctional agriculture'.

He cooperates with universities in the Green Care project by investigating the medical results of onfarm health services, and has worked with schools to develop an educational programme on farms. $\mathrm{He}$ started Landzijde as a commercial organisation without volunteers and places great importance on client satisfaction: 'Heart and soul have to be committed to the client'. The board of the organisation consists of non-farmers: 'Progress is made with people who have the insight, vision and entrepreneurial passion for the whole. I learned a lot from people working outside agriculture.' His passion and enthusiasm are evident; he prefers to see opportunities instead of obstacles and communicates his message with persistence. He also set up My Farm, an organisation which develops regional products. My Farm cooperates with Amsterdam on developing a more sustainable food strategy. One of the outcomes of this was the opening of the cooperative supermarket Marqt in the centre of Amsterdam in February 2007. This shop sells quality products from the farmers in the Waterland region and functions as a marketplace, so no storage space is needed. The left-wing Amsterdam executive councillor supported the project because it fits in well with Amsterdam's city promotion and food strategy.

Besides being a networker, Jaap Hoek Spaans can be described as a 'battering ram' because of his perseverance in working across boundaries. He realises the danger of an organisation being dependent on the leader. 'One of the dangers is that the publicity focuses too much on one person,', he says, and so he has already appointed his successor. As a pioneer, he does not consider himself the best person to lead an established organisation.

\section{Case 2: A health manager as project developer of integrated communities}

Heuvelland, which means 'land of hills', is a metropolitan landscape in the south of the Netherlands between the cities of Maastricht, Heerlen and Sittard. Heuvelland is a National Landscape and one of the oldest tourist regions in the Netherlands. The landscape is characterised by rolling hills, forests, brooks, sunken lanes and meandering rivers. Heuvelland is becoming a 'post-productive landscape', where new functions related to urban needs are becoming more important as drivers of the economical vitality of the region than agriculture.

In Heuvelland a regional process was started, 'the New Markets approach', to develop new inter-sector markets linked to territorial qualities such as the landscape (ZKA et al, 2005). One of the projects in this regional process was 'Healing Hills', a new coalition between Orbis Medical and Healthcare Group in Limburg, the hospitality company Château Hotels, who signed a contract with a national insurance company for two holiday and healthcare packages allowing surgery patients to recover in a 3 or 5 star hotel set in an attractive landscape.

Guus Broos - being a member of the management board of Orbis Medical and Healthcare Group - was one of the initiators of the Healing Hills project and can be seen as a leader in regional change. He is a visionary type of leader, with a clear vision for the future of medical care. In his view, the care sector 
will be too expensive in the near future and has to become more patient-oriented and less patronising towards clients: 'We have to create healing environments with an emphasis on wellness. This implies the dismantling of traditional care structures and building the delivery of care around the needs of the client, rather than the production of care.'

He was one of the creative initiators of the new 'hospital of the $21^{\text {st }}$ century' in Sittard (Derix 2003), and developed the concept of 'integral care communities in the region'. These are care facilities in a village or town or in the countryside that are integrated with other regional services like recreation, wellness, childcare and food supply, and with the landscape. An urban example is Parc Hoogveld in Sittard. This initiative started as a care centre for elderly people, but developed into a multifunctional service centre for the city community, including the development of a large park.

As a sociologist who has worked in a broad variety of organisations, Broos was able to build bridges between actors in different settings, both at the strategic and operational levels. He is aware of the benefits of operating in both a formal and an informal network: 'I operate in two networks. First, my informal network contains free spirits like architects, people from religion, business and spirituality. These are people who want to stick their neck out. Second, my formal network consists of people from government, trade and industry associations, businesses and NGOs. They don't feel the need innovate. Some people belong to both networks.' Personal contacts play an important role in his activities. His personal empathy with the director of Castle Hotels in Limburg underpinned the development of the innovative Healing Hills concept. His motivation is to create so called 'healthy environments': 'Care is now stigmatising. When people grow old and need services and a housing landscape, they want a trustworthy environment with advanced care and cure' (Derix, 2003). The development and exploitation of the park is funded mainly by private partners, such as housing corporations and investors, who want to create an attractive meeting space for clients and citizens. Broos's networking capabilities, charisma, persuasive skills and status as a member of the largest care organisation in the region were crucial in getting these private developers to support the project and cooperate in its development (Horlings and Haarmann, 2009). His plan is to develop not only urban centres, but also small-scale communities on farms that integrate housing, care and recreational functions. To achieve this, new alliances are necessary.

Broos was able to influence decision makers at local and provincial level and created synergy between initiatives, for example by participating in the regional branding process in South Limburg. He is driven not only by a desire to develop new projects, but also to stimulate social cohesion, new communities and voluntary work. 'Parc Hoogveld is based on the concept of the community; it is an urban community. The goal is to realise a housing, employment and recreational environment that creates social cohesion and a sense of belonging and commitment by combining public and private functions.'

This story has however not a happy ending. This leader of change was confronted with the high costs of building the new hospital. His formal position came under pressure during the financial crisis in 2008 and he had to step down. Orbis focused on its core business and jettisoned its innovative and pioneering activities.

\section{Case 3: A strawberry producer in Het Groene Woud}

The National Landscape 'Het Groene Woud'- which means Green Forest - is situated in the triangle between the cities of Den Bosch, Tilburg and Eindhoven. In this region, Frans van Beerendonk, a strawberry producer, took the initiative to start a regional branding process with the aim of marketing the key values of the region. As a member of the Sustainable Meierij Innovation Group, he encouraged the development of activities to learn from other regions in the Netherlands and Europe. His ideas emerged during an inspiring visit to the Cork region in Ireland where public and private partners market regional products ranging from home-made food to four-star hotels.

After the trip to Cork a group of entrepreneurs was formed to turn the concept of branding into commercial opportunities and market regional products. A label for their products was launched in November 2007 and in 2008 a commercial cooperative association with 30 members was formed to market the regional products, and a further 160 interested entrepreneurs were asked to join the cooperative. With help of a commercial advisor, who also feels personally committed to the region, the group developed a business plan to develop broad sustainability criteria at the business as well as the product level. Their first step was to make agreements with farmers about habitat management and development. In 201050 farms were certified and now produce under the 'Groene Woud' label. The group then sought cooperation with other regions developing similar activities, such as the Kempen region and the Maashorst in Noord-Brabant. The project in Het Groene Woud also wants to develop new relations between the region and the triangle of cities around it: Den Bosch, Eindhoven and Tilburg. 
Van Beerendonk's passion is rooted in his commitment to his own region: 'I want the region to remain attractive for its inhabitants and for visitors. I want people to become reconnected to their region, so that they can talk about the region with pleasure.' The entrepreneur can be seen as a networker. He has a clear message, which is promoting networking with all kinds of partners inside and outside the region and stimulating people to work together on a voluntary basis for the region. His goal is to develop a regional economy that contributes to the quality of the valuable small-scale landscape. Crucial to realising this goal is getting the commitment of the three cities and non-agricultural businesses: 'The big cities are neglecting their backyard. Businesses that benefit from the countryside should contribute to sustainability. This is how to develop a regional economy'. He believes the development of the region should be based on regional characteristics and values, such as the environmental qualities of the diverse landscapes, the current variety of economic activities, and the social cohesion and cooperation between the people living in the region.

Van Beerendonk is the initiator and chairman of the annual regional Green Forest Festival, which is organised by many local volunteers and receives about 20,000 visitors each year. This case shows that regional development requires shared leadership. It illustrates that passion and individual action is important for regional development, but also cannot be reduced to an individual feat alone: it takes more than a visionary individual to "get things done collectively". Here also a local elderman and the commercial advisor of the entrepreneurs' group played a leading role.

Het Groene Woud is a dynamic region where many different activities take place and many projects are carried out, but it has led to organisational fragmentation, a pitfall for the regional process.

Consequently, van Beerendonk spends much energy on aligning people and organisations around a joint agenda. In his vision, the region can only be promoted if entrepreneurs, recreational organisations, NGOs and landscape and nature conservation organisations all work together.

Case 4: A farmer-philosopher involved in multifunctional agriculture

The Eemland Farm is a 'farm plus', with a wide variety of activities which functions as a centre of regional development in this area. It also functions as an incubator for new rural concepts and ideas on different scales. The Farm is a demonstration business for multifunctional farming started by Jan Huijgen, an entrepreneur who sees himself as a farmer, philosopher and lecturer. He studied at Wageningen Agricultural University (now Wageningen UR) and philosophy at the University of Amsterdam, where he was introduced in the ideas of Heidegger, Habermas and Lyotard: 'The distance between farmers and civilians created an unpleasant feeling. Perhaps that's why I studied philosophy. I learnt about the idea that there is an emptiness behind the technical control mechanisms in current society; people are not rooted and need a new foundation, a sense of belonging to a place that feels like home.'

He also studied environmental philosophy and theology for a while and was a lecturer at an agricultural school, but science turned out to be not the right path for him: 'I always sought the frontiers. I was too curious and hard-headed to become an ordinary farmer, but also too much involved in agricultural practice to be a philosopher. I didn't have the patience for writing books. I have too much passion and energy.' He realised that his strength does not lie in doing one job, but in combining different roles. His decision to diversify the activities on his farm meant he had to let go of his expectations and desires following a period of crisis: 'I had to sell some land, but when you take away a farmer's land you take his soul. Traditional farming means developing the farm, not selling the land. After this horrible process, everything fell into place. The minister started to talk about rural renewal. I had waited for years for that moment'.

Huijgen is a very clear example of a 'network shuttle' because he connects networks on different geographical scales. For example, he started an association for farmland conservation management in the National Landscape. On a higher level, he founded a rural-urban cooperation network with other associations to stimulate multifunctional agriculture in the Netherlands. Eemland Farm also became a regional innovation centre in March 2008. Its purpose is to collate expertise to answer questions that arise in practice, and to stimulate innovation and integration with student education by establishing a 'Rural Academy' (see Roep et al. 2009).

Huijgen was awarded the 2007 Sicco Mansholt prize for his dedication to multifunctional agriculture and rural-urban alignment. He wants, in his own words, to 'stimulate meetings between farmers and citizens, between the city and the countryside and between creator and creation.' In 2007 he was the driving force behind a conference 'City Seeks Farmer', which was held at Eemland Farm. During this conference the Amersfoort Agreement (Akkoord van Amersfoort) was presented to the Minister of Agriculture, Nature and Food Quality. The goal of this voluntary agreement is to strengthen the relation between the built-up area and the green rural environment by developing concrete local projects. 
This pioneer's passion is rooted in his agricultural and Christian background. 'I have never renounced my agricultural roots. During my education I always had the feeling that I have to maintain this connection with the love for nature, God's creation, farmer's culture. As a Christian I feel responsible for a sustainable world and caring for God's creation.' He believes that farming is a way of living life as it is intended by God. 'You are in direct contact with nature and the greatness of God's creation. As a result you look at society from the right perspective'. He is a philosopher with a mission who sees farmers as managers of the landscape: 'In the agricultural tradition you see the richness of the relations with the elements, the biological rhythm and the care for people and animals. These standards are of great importance in our society, which is drifting. I see it as my task to bring people into contact with the farm, nature and the way food is produced'.

\section{Empirical findings in eight cases}

Above we have described four leaders in the Netherlands. In total eight cases have been analyzed where leadership plays an important role. In the next sections we will describe the main findings in these cases based on the leadership model we have developed. This will show how the I, WE, IT and THEY dimension plays out in regional development.

\subsection{Shared leadership}

Above we characterized shared leadership (the WE dimension) as dealing with different visions and values in networks. The type of leaders, the tasks they performed and their capabilities were analyzed to explain this dimension. Following Sotarauta's typology of leaders of Sotarauta (2002: 197-203) two main leadership types were identified: 'networkers' and 'visionaries'. Networkers are cooperationoriented, prepared to discuss and to look for common interests. They are able to connect people of different worlds, either public or private. Visionaries have imagination and the ability to see the bigger picture, but they also get easily bored with details, may seem superficial and impatient, or can lose touch with their own network or region. Some of the leaders in the case studies also acted as 'battering rams' when facing resistance against their ideas. Battering rams are very goal-oriented. They use all possible means from seducing to negotiations to forcing in order to get what they want: they talk, convince, envision, network, and try to change the rules of the game. A pitfall for leaders is isolating themselves from others, by 'walking too far before the troops'. One of the leaders expressed this as follows: 'In the harsh light of reality it is difficult to stay on track, and there is a risk of becoming isolated'.

The leaders mobilized people around an issue. We identified four types of mobilisation: mobilising entrepreneurs to form a business community;

mobilising policy actors around a joint agenda to frame new perspectives for the region; mobilising volunteers and professionals to organise events; mobilise knowledge workers to strengthen their own insights and knowledge.

The leaders made tangible achievements. The leaders reached specific achievements in regional networks. They raised awareness about their goals, rooted in value-based views on sustainable regional development, which resulted in concrete initiatives. Examples include a new form of self-governance of farmers in the Northern Frisian Woods, the implementation of entrepreneurial sustainability in 'Het Groene Woud', aims to take responsibility for the quality of the rural landscape, so called ' integral community building' combining housing, health care and entrepreneurial activities in Limburg, and a new concept for more sustainable intensive farming with closed loops of energy, water and minerals in the case New Mixed Business.

The respondents were also asked which capabilities they used in their daily work, and what they consider to be their strengths and weaknesses. The results indicate that the initiators in the Dutch cases are mostly pragmatic. They focus more on using networks than on building new institutions. Networking capabilities are very important, especially in the Dutch situation where government planning is fragmented and regional issues involve a complex web of different interests and organizations. All respondents communicated intensely with a wide variety of public servants, repeating their message time and again. The most successful leaders were able to connect different networks and scale up their activities to larger networks. Another capability is strategic thinking, trying to influence decision making at the right moment. Some of the respondents noticed they have a tendency to express new visions and ideas that are too radical for others to take on board, and the associated danger of decreasing commitment from other entrepreneurs. Another pitfall is the danger of adapting too much to government timetables, like one of the leaders expressed clearly: 'I have become 
more flexible. I find it normal now that things take more time. This is also a risk. People often ask me when we can start building. I fight against delays less than I used to.'

A capability that seems to be undervalued is the capacity to raise excitement. Yet, some respondents tried to do this by organizing events, conferences or regional festivals to mobilize people and stimulate commitment to the region.

In concluding, along the WE dimension leaders act as visionary networkers, mobilize people and raise awareness to reach achievements using a wide range of capabilities.

\subsection{Creating a vital space for action}

Key to leadership along the IT dimension is to stimulate favorable behavior and to create 'vital space' for sustainable development. Leadership roles and coalitions were explored to explain this dimension. Leadership roles appeared not to be fixed but flexible, anticipating the situation they found themselves in. The initiators saw themselves in the first place as 'inspiring people' and the outside world appeared to recognize this role. The initiators expressed strong opinions with enthusiasm and perseverance to put new issues on the agenda and strongly advocated new concepts. Most respondents recognized themselves in the role of 'prophet', but preferred the term 'visionary'. They also recognized the danger of losing touch with their own group. Acting as a 'clown' or 'regulator' (explained above) was mentioned as the least important roles.

The leaders contributed to new 'vital coalitions' between private actors and between private and public actors. These coalitions were informal, energizing and aligned people around a new storyline, thereby creating capacity to act (see also Van Ostaaijen et al., 2010). The research indicated there are three important conditions for establishing such coalitions. First, there needs to be a solid business community of entrepreneurs with a common goal and agenda. Establishing such a community is not easy because of the inevitable differences in interests and visions, lack of trust and loss of autonomy, and communication problems. Second, government officials need to support the coalitions. This requires political power, courage and vision from governments. Third, reflection, regular communication and the use of formal and informal rules on how to work together are needed. Some initiatives organized reflection meetings on a regular basis, which enabled the participants to share their feelings and expectations, explain their roles and build trust and commitment.

In conclusion, along the IT dimension leaders build vital space where effective regional cooperation is possible, using flexible roles. They contribute to vital coalitions between private businesses as well as between private and public actors.

\subsection{Bricolage, bridging different worlds}

Leaders can help connecting networks and institutional arrangements along the THEY dimension to cope with new sustainability challenges. When doing so they frequently experience a 'glass ceiling' of institutions, rules and dominant ideas. The empirical research revealed a series of strategies leaders followed to break through this ceiling and to create capacity to act (see also Horlings, 2010). Three such strategies are explained here. First, leaders contributed to the framing of problems by telling their story over and over again. They tried to bring the shared vision developed in networks (the WE dimension) across to those with formal positions and power to set the agenda. Second, leaders looked beyond their own network in search for knowledge, a strategy referred to as 'open innovation' (Chesbrough, 2003). In the case study areas new coalitions were formed with knowledge institutes. Leaders also tried to adapt lessons learned in other regions to their own region. Third, leaders tried to change the rules of the game. In the case studies leaders effortlessly moved between the different worlds of policy, practice and science at different levels. When they felt obstructed by local civil servants, they mobilized supporters for their plans at higher levels of governance ('leapfrog strategy'). Or they created opportunities for negotiations 'behind the scenes' and used their position, status or personal competences to exert influence through informal contacts and political pressure as one of the leaders expressed: 'Many things got done during informal chats outside meetings. I know a lot of people. I can get attention. I phoned the decision maker on Friday night. He came immediately on Saturday morning to our board meetings.' There is however the pitfall of incorporation. One of the entrepreneurs expressed this as follows: 'If the process becomes too institutionalised, you lose your freedom'. In difficult situations where the danger of a deadlock is ever present, one strategy is to use the media to exert political pressure. An example from the case Overdiepse polder: 'I phoned X and said that if the plan fails the news would be on television, and the failure would be attributed to bureaucratic inertia and the laziness of the government officers.' 
To summarize, along the THEY dimension leaders apply different strategies of agenda setting, open innovation and rule changing and in doing so they are able to connect their network in wider social systems to cope with sustainable challenges.

\subsection{The X-factor}

The research revealed preliminary insights about the motivations and passion of leaders (the I dimension). First, the results showed leaders shared several common personal qualities. The respondents were all men of at least 40 or 50 years old. They had gained the experience and had the time to do this work (for example, those with a farm had a successor running the farm). This is important because it needs focus as well as perseverance, self-will, energy and patience to keep going during often long-lasting regional processes. Other relevant personal qualities included self-reflection, an open mind for new knowledge and the use of variable multilevel networks.

Leaders also face some pitfalls such as being to convincing, forcing or overpowering, losing contact with their own network or getting bored with details. The importance of dealing with one's own character was clearly expressed by one of the leaders: 'The resistance is in me. It is about finding my own strength. My inner ego hampers contact with others. I can be overpowering and hurried, which is a risk when making contacts. It is about engaging with the established regime and revealing your vulnerability to show you are being open.'

Second, the leaders of change were not solely motivated by their own private interests but had feelings and an awareness of environmental problems, animal welfare and sustainable production (among others).Their agendas were rooted in, and also went beyond, individual personal and business goals. In this sense, the initiators functioned as ambassadors of collective sustainability goals. The farmers of the Northern Frisian Woods Association for example developed a management model to realize environmental goals that were more ambitious than those laid down in national policy plans. In 'Het Groene Woud', a national landscape, entrepreneurs developed a branding strategy for the region, integrating economic, social and ecological aspects. The organizations Landzijde, Eemlandfarm and the Association Northern Frisian Woods broadened agricultural practices with new rural products and services, thereby contributing to the quality of life, multifunctional agriculture and sustainable landuse. Thirdly, the results showed the importance of personal motives and values of the leaders. Some felt inspired to maintain the quality of the landscape and others to connect with other people. More egocentric motives also played a role; some leaders liked to be in the spotlights as pioneers and innovators and having influence. Finally, spiritual or religious beliefs were important for some. The conclusion here is that along the I dimension the $\mathrm{X}$-factor can partly be explained by personal qualities, environmental feelings and awareness, and personal motives and values.

\section{Conclusions; leadership as agenda-setting and mobilizing factor in regional sustainable development}

In this paper we have argued that the role of 'the human factor' in regional development is often underestimated. We specifically analysed the role of leadership. Leadership plays a crucial role in reinventing regions and branching out from an old 'economic' path to something new in order to create more sustainable regional development. Leadership is not something magic or an easy solution to complex problems. It is a profession based on individual skills. In this paper we used a value oriented leadership model for sustainable regional development based on theory and empirical findings. In our opinion this framework provides a useful framework for analyzing value-based leadership for sustainable regional development.

This paper has tried to open the 'black box' of leadership in regional development by analyzing what people actually do and by shedding more light on the relation between the outer, (inter-)objective and the (inter-)subjective dimension of leadership. Table 3 summarizes the main findings of the last sections ordered along the axes of an inner-outer and an individual-collective dimension. 
Table 3. Dimensions and operational criteria for leadership for regional development.

\begin{tabular}{|c|c|c|}
\hline & Inner World & Outer World \\
\hline Individual & $\begin{array}{l}\text { 'The X-factor' } \\
\text { personal qualities } \\
\text { feelings and awareness } \\
\text { inner motives and values }\end{array}$ & $\begin{array}{l}\text { 'Vital space' } \\
\text { flexible roles } \\
\text { vital coalitions }\end{array}$ \\
\hline Collective & $\begin{array}{l}\text { ‘Shared leadership’ } \\
\text { leadership type } \\
\text { achievements } \\
\text { capabilities }\end{array}$ & $\begin{array}{l}\text { 'Bricolage' } \\
\text { agenda setting } \\
\text { open innovation } \\
\text { rule changing }\end{array}$ \\
\hline
\end{tabular}

The individual inner I-dimension or the 'X-factor' can be explained by personal qualities, feelings and awareness about the environment and inner motives and values. The individual outer IT dimension entails building 'vital space' where effective regional cooperation is possible, using flexible roles. The collective inner WE dimension is about 'shared leadership'. Different leadership types (networkers and visionaries), tangible achievements and capabilities are needed to bring together a variety of visions. Leadership along the collective outer THEY dimension means dealing with different institutional contexts. By 'bricolage', i.e. applying different strategies of agenda setting, open innovation and rule changing, they connect their network to the institutional environment to cope with sustainability challenges.

The scope of the leaders' visions and their actions and ambitions differ from case to case. Their agenda may be more business-oriented (for example, the New Mixed Business and the Sjalon business partnership) or region-oriented (Het Groene Woud, Northern Frisian Woods). The concept of sustainability varies, from a focus on environmental aspects (New Mixed Business, Northern Frisian Woods) to a broader perspective, including ecological, socio-cultural and economic aspects (Het Groene Woud). Socio-cultural aspects were underestimated in most cases. Furthermore, the inner motives of the respondents and what drives them to pursue their own particular vision of sustainability differed considerably.

The leaders have a proactive, flexible attitude, are creative, and link their private goals to future perspectives for their region. The qualities they need include patience to maintain momentum in the often lengthy processes, as well as open-mindedness, self-will, self-reflection and perseverance. Motivating people is what they do best, by telling their story over and over again, visioning between visions and contributing to the framing of new issues and agendas. However, they face the risk of exhaustion, running too far ahead of the pack, and getting bogged down in discussions about rules and structures. We distinguished three important success factors for creating 'vital' coalitions with other private and public actors :

Establishing a solid business community of entrepreneurs with a common goal and agenda is a good starting point for forming coalitions with other actors. It is import to maintain the autonomy of individual group members.

Backing from government authorities often turns out to be crucial. To avoid fragmentation within the provincial organisation, government support preferably should take place outside the provincial government departments, for example by establishing a development agency with the capacity and powers to implement regional programmes.

Reflection, regular communication and the use of formal and informal rules on how to work together are important. Some initiatives organised reflection meetings on a regular basis to share feelings and expectations, explaining the roles to be played by those involved and building trust and commitment. 
Based on the results presented in previous sections, we conclude that leadership in regional networks requires special skills, competences and roles. Sustainable regional development benefits from shared leadership where collective values, feelings, trust, commitment and energy form the basis for mobilising private and public actors around a joint agenda in regional networks.

The empirical analysis showed that leaders help to raise awareness in the region and play a sensemaking role, telling their stories and trying to align people around sustainability issues. Leaders can in this sense contribute to the framing of new regional concepts and agenda's and the exploration of new pathways to sustainability. When trying to introduce alternative pathways to the future, leaders experience regime power as a glass ceiling of institutions, rules and dominant ideas. In networks they pursue different strategies to remove 'frozen shapes' and lock-ins. They can contribute to the forming of new vital coalitions leading to more capacity to act within the institutional context.

\section{References}

Bridger, J.C., Alter, T.R. 2008. An interactional approach to place-based rural development. Community Development: Journal of the Community Development Society 39 (1): 99-111.

Chesbrough, H.W. 2003. Open Innovation: The New Imperative for Creating and Profiting from Technology. Harvard Business School Press: Boston.

Collinge, C. Gibney, J. 2010. Connecting place, policy and leadership, Policy Studies $\underline{31}$ (4), 379 391.

Collinge, J., Gibney, J., Mabey, C. 2010. Leadership and Place. Routledge: Abingdon Oxford, UK.

Cooperrider, D. L., Whitney, D., Stavros, J.M. 2008. Appreciative Inquiry Handbook for Leaders of Change. Crown Custom Publishing: Brunswick, OH.

Cuthill, M. 2010 Strengthening the 'social' in sustainable development: Developing a conceptual framework for social sustainability in a rapid urban growth region in Australia. Sustainable Development 18 (6), 362-373.

Derix, G. (2003), Hof der Onthaasting. Werkboek, Orbis: Sittard.

Gibson-Graham, J.K. 2008. Diverse economies: Performative practices for other worlds. Progress in Human Geography 32 (5), 613-632.

Hay, R. 2010. The relevance of ecocentrism, personal development and transformational leadership to sustainability and identity. Sustainable Development 18 (6), 163-171.

Hedlund-de Witt, A. in press. The rising culture and worldview of contemporary spirituality: A sociological study of potentials and pitfalls for sustainable development. Ecological Economics.

Horlings, I. 2010b. Vitality and values: the role of leaders of change in regional development. In Vital Coalitions, Vital Regions: Partnerships for Regional Sustainable Development, Horlings, I. (ed). Academic Publishers: Wageningen; 97-126.

Horlings, I., van Mansfeld, M. 2006. Back to BSIK? Integrated Project Green Valley. Process report Green Valley. Telos and TransForum: Tilburg.

Horlings, I., Haarmann, W. 2008. Botsende belangen en vitale verbindingen. Position paper over het Integrated Project Nieuwe Markten en Vitale coalities Heuvelland. In Nieuwe Markten en Vitale Coalities Heuvelland Zuid-Limburg, TransForum (ed). Working paper no. 8. TransForum: Zoetermeer; 95-174.

Horlings, L.G., Padt, F. Leadership for Sustainable Regional Development in Rural Areas: Bridging Personal and Institutional Aspects. Sustainable Development, in press.

Horlings, I., Remmers, G., Duffhues, T. 2009. Bezieling: de X-factor in Gebiedsontwikkeling. Salsedo: Breda.

Jones, R., Noble, G. 2008. Managing the implementation of public-private partnerships. Public Money \& Management 28 (2), 109-114.

Klein, E., Teisman, G.R. 2003. Institutional and strategic barriers to public-private partnership: an analysis of Dutch cases. Public Money and Management 23 (3), 137-146.

Larkin, K., Cooper, M. 2009. Into Recession: Vulnerability and Resilience in Leeds, Brighton, and Bristol. Centre for Cities: London.

Liddle, J. 2003. A Regional Regime. University of Warwick UK, unpublished thesis.

Millennium Ecosystem Assessment 2005. Ecosystems and Human Well-being: synthesis. Island Press: Washington DC.

Milner, E. M., Joyce, P. 2005. Lessons in Leadership: The Challenge of Public Services. Routledge: Abingdon Oxford, UK.

Noble, G., Jones, R. 2006. The role of boundary-spanning managers in the establishment of publicprivate partnerships. Public Administration 84 (4), 891-917. 
OECD (2006). The new rural paradigm: policies and governance. Organisation for Economic Cooperation and Development: Paris.

Pike, A., Tomaney, J., Rodriguez-Pose, A. 2006. Local and Regional Development. Routledge: London.

Pike, A., A. Rodriguez-Pose, J. Tomaney (2007). What kind of local and regional development and for whom? Regional Studies 41 ( 9), 1253-1269.

Quental, N., Lourenço, J.M., Nunes da Silva, F. 2011. Sustainable development policy: Goals, targets and political cycles. Sustainable Development 19 (1), 15-29.

Rajeswar, J. 2010. Deconstructing the development paradigm: a post-structural perspective. Sustainable Development 18 (6), 245-251.

Roep, D., I. Horlings, Wielinga, E. (2009). Kennismaken met regionale kennisarrangementen, report, LEI, Wageningen.

Rowley, R.M., Roevens, J.J. 1999. Organize with Chaos: A Simple Robust Business Tool. Management Books 2000 Ltd: Gloucestershire.

Scharmer, C.O. 2005. Theory U: Learning from the Future as it Emerges. Berrett-Koehler Publishers: San Francisco, CA.

Scharmer, C.O. 2008. Uncovering the Blind Spot of Leadership. Leader to Leader, 2008(47), 52-59.

Schön, D.A. 1973. Beyond the Stable State. Public and Private Learning in a Changing Society. Penguin: Harmondsworth.

Schön, D.A. 1983. The Reflective Practitioner. How Professionals Think in Action. Temple Smith: London.

Sotarauta, M. 2002. Leadership, power and influence in regional development: a tentative typology of leaders and their ways of influencing. In Perspectives on Process-Based Regional Development Policy, Sotarauta, M., Bruun Nordic, H. (eds). Nordregio: Stockholm; 182-207.

Sotarauta, M. 2005. Shared leadership and dynamic capabilities in regional development. In Regionalism Contested: Institution, Society, Governance, Sagan, I., Halkier, H. (eds). Aldershot: Ashgate; 53-72.

Sotarauta, M. 2006. Where have all the people gone? Leadership in the fields of regional development. Sente Working papers 9/2006. Research Unit for Urban and Regional Development Studies. University of Tampere: Tampere.

Stimson, R., Stough, R., Salazar, M. 2009. Leadership and Institutions in Regional Endogenous Development. Edwar Elgar Publishing Ltd, Cheltenham.

Tarnas, R. 2008. The modern self and our planetary future: a participatory view. Paper presented at the symposium De binnenkant van duurzaamheid, March, 5, 2008, The Hague, the Netherlands.

Van Mansfeld, M, van der Stoep, H. 2007. Procesverslag Heuvelland. Wageningen: Wageningen University and Research Centre: Wageningen.

Van Ostaaijen, J., Horlings, I., van der Stoep, H. 2010. Conditions for vital coalitions. In Vital Coalitions, Vital Regions: Partnerships for Regional Sustainable Development, Horlings, I. (ed). Wageningen Academic Publishers: Wageningen; 157-175.

Vries, B.J.M. de, Peterson, A.C. 2009. Conceptualizing sustainable development: An assessment methodology connecting values, knowledge, worldviews and scenarios Ecological Economics 68 (4), 1006-1019.

WCED (1987). Our Common Future. World Commission on Environment and Development, Oxford University Press: Oxford.

Wilber, K. 2000. Integral Psychology: Consciousness, Spirit, Psychology. Therapy. Shambhala Publications: Boston.

Wielinga, H.E. 2001. Netwerken als Levend Weefsel: Een studie naar kennis, leiderschap, en de rol van de overheid in de Nederlandse landbouw sinds 1945. Dissertation. Wageningen University and Research Centre: Wageningen.

Wielinga, H.E. 2005. Het Assisteren van Kennisnetwerken, Netwerken, Verbindingen en Interventiestrategieën. Landbouw Economisch Instituut: The Hague.

Wiskerke, J.S.C. 2007. Robuuste regio's: dynamiek, samenhang en diversiteit in het metropolitane landschap. Inaugural lecture, Wageningen University and Research Centre: Wageningen.

ZKA, Urban Unlimited en Universiteit van Tilburg (2005), Heerlijkheid Heuvelland; nieuwe markten en allianties voor toerisme in het Heuvelland, LIOF: Maastricht.

Zoeteman K, 2009, Gaia logica, een nieuwe manier om met de aarde om te gaan. Christofoor: Zeist. 